\title{
NAMES OF CUCKOO AND CUCKOO CHICK IN RUSSIAN FOLK LINGUISTICS ${ }^{1}$
}

\author{
Evgenia V. Brysina \\ Volgograd State Socio-Pedagogical University, Volgograd, Russia \\ Vasiliy I. Suprun \\ Volgograd State Socio-Pedagogical University, Volgograd, Russia
}

\begin{abstract}
The research is carried out in the context of ethnolinguistics, which is aimed at analyzing nominations of ecosystem objects as means of presenting relations between language and culture, and in particular, specificity in their perception by various ethnical and subethnical (dialect) groups. The authors rely on two suppositions: though flora and fauna are reflected diacritically in linguistic consciousness of various dialect communities due to physical, geographical, social environment, there exist some universal lexical and phraseological language means to describe every object of nature. The purpose of the article is to determine the regularities in nomination of the cuckoo as a significant linguocultural representative of fauna. The material for the study was the card file of the Linguistic Atlas of Russian folk dialects, stored at the Institute for linguistic research of the Russian Academy of Sciences (Saint Petersburg). The research has shown that the nominations of the cuckoo and the cuckoo chick have special implications in the linguistic consciousness of the Russian people. These units have onomatopoietic origin, they have undergone phonetic, derivational and semantic transformations in the Russian dialect continuum. Ornithonyms implement a binary semantic correlation, linking the sphere of living nature, to which they belong by denotative features, and the human character - the area where their development of connotative-contextual semantics leads, due to the specifics of the linguocreative thinking of the language personality.
\end{abstract}

Key words: linguistic consciousness, ethnolinguistics, linguistic culture, dialect, perception of the world, ornithonym.

Citation. Brysina E.V., Suprun V.I. Names of Cuckoo and Cuckoo Chick in Russian Folk Linguistics. Vestnik Volgogradskogo gosudarstvennogo universiteta. Seriya 2. Yazykoznanie [Science Journal of Volgograd State University. Linguistics], 2020, vol. 19, no. 4, pp. 16-28. (in Russian). DOI: https://doi.org/10.15688/jvolsu2.2020.4.2

\section{НАЗВАНИЯ КУКУШКИ И КУКУШОНКА В РУССКОМ НАРОДНОМ ЛИНГВОСОЗНАНИИ ${ }^{1}$}

\section{Евгения Валентиновна Брысина}

Волгоградский государственный социально-педагогический университет, г. Волгоград, Россия

\section{Василий Иванович Супрун}

Волгоградский государственный социально-педагогический университет, г. Волгоград, Россия

Аннотация. Исследование выполнено в русле этнолингвистики, которая при изучении отношений между языком и культурой, выявлении особенностей восприятия мира разными этническими и субэтническими (диалектными) группами обращена к номинированию носителями языка объектов окружающей экосистемы. Авторы опираются на положения о том, что мир флоры и фауны отражается в лингвосознании различ- 
ных диалектных сообществ дифференцированно, в зависимости от физико-географических и социальных условий мест проживания человека, и что существуют универсальные лексико-семантические и фразеологические средства языка, относящиеся к тому или иному объекту природы. Цель данной статьи состоит в определении специфики номинативных процессов, связанных с называнием значимого в лингвокультурном плане представителя фауны - кукушки. Материалом для анализа послужила картотека Лингвистического атласа русских народных говоров, хранящаяся в Институте лингвистических исследования РАН(Санкт-Петербург). Исследование показало, что наименования кукушки и кукушонка занимают особое место в лингвосознании русского народа. Эти единицы имеют ономатопоэтическое происхождение, они претерпели в русском диалектном континууме фонетические, деривационные и семантические преобразования. Орнитонимы реализуют бинарную семантическую корреляцию, связывая сферу живой природы, к которой они принадлежат по денотативным признакам, и сферу человеческого характера - область, куда приводит развитие их коннотативно-контекстуальной семантики, обусловленное спецификой лингвокреативного мышления языковой личности.

Ключевые слова: лингвосознание, этнолингвистика, лингвокультура, диалект, мировосприятие, орнитоним.

Цитирование. Брысина Е. В., Супрун В. И. Названия кукушки и кукушонка в русском народном лингвосознании // Вестник Волгоградского государственного университета. Серия 2, Языкознание. - 2020. - Т. 19, № 4. - C. 16-28. - DOI: https://doi.org/10.15688/jvolsu2.2020.4.2

\section{Введение}

Исследование посвящено актуальной для современной этнолингвистики проблеме выявления содержания и формирования лингвосознания носителя народной речи. Цель данной работы - на обширном языковом материале показать особенности восприятия носителем русского языка кукушки как одного из ставших частью традиционной русской культуры объектов окружающей действительности.

Языковая личность обобщает в словах, словосочетаниях, предложениях и текстах свое восприятие мира и отношение к нему. Большое значение в жизни человека играет мир фауны. Наблюдения за поведением животных, особенностями их жизни, знания об утилитарной полезности и эстетическом восприятии внешнего облика объекта вербализуются в языке, и особенно в диалекте, многочисленными единицами, часто становясь основой для фольклорных произведений. В статье в этнолингвистическом аспекте рассматриваются языковые единицы, номинирующие кукушку и ее птенца.

\section{Материал и методы исследования}

Материалом исследования послужила картотека Лингвистического атласа русских народных говоров (далее - ЛАРНГ), хранящаяся в Институте лингвистических исследования РАН (Санкт-Петербург).
Сетку обследования атласа составляют около 1070 пунктов на территории европейской части России. Программа атласа включает более 5 тысяч вопросов по макротемам «Природа», «Человек», «Растительный мир», «Материальная культура». В рамках темы «Природа» проводился сбор материала о номинациях животных в русском диалектном континууме, включая названия птиц. Две карты готовящегося к изданию тома ЛАРНГ, составление которых поручено авторам настоящей статьи, посвящены названиям кукушки и кукушонка. При обработке материала были использованы диалектные, этимологические, толковые словари русского языка и фольклорные тексты.

При разработке проблемы и реализации цели исследования применялись такие общенаучные методы, как обобщение, абстрагирование, формализация, анализ, синтез; основным лингвистическим методом стал дескриптивный, позволивший выявить исследуемые единицы языка и системные отношения, в которые они вступают. Изучались качественные свойства диалектных названий кукушки, определена количественная представленность лексем в народной речи. Историко-сравнительный метод использовался для определения диахронических преобразований орнитонимов, элементы сопоставительного метода - при выявлении ономатопоэтической природы названий кукушки в разных языках. 


\section{Результаты и обсуждение}

В лингвогенезе разных этносов кукуш$\boldsymbol{\kappa} \boldsymbol{a}$ отразилась яркой ономатопоэтической номинацией. В самых отдаленных по родству и даже в неродственных языках (если не учитывать моноцентрическую теорию глоттогенеза) кукушку именуют словами, указывающими на ее крик: рус. кукушка, болг. кукувиu̧a, серб. кукавица, чеш., словац. kukačka, польск. kukutka, хорв., словен. kukavica, нем., люксем. Kuckuck, англ. cuckoo, нидерл., африкаанс koekoek, дат. gøg, норв. gjøk, швед. gök, gökur, идиш קוקו [куку], фр. соисои, исп. cuclillo, ит. cuculo, порт., галисийск. сисо, рум. cuc, каталан. cucut, греч. кои́коৎ, алб. eqyqes, валлийск. gog, венг. $k a k u k k$, фин. $k a ̈ k i$, эстон. $k a ̈ g u$, удмурт. кикы, горно-мар. куку, груз. зэзиэмо [гугули], баск. kuku, турец. guguklu, башк. кәкүк, татар. күке, кәккүк, узбек. qo'qon, иврит קוק [коко], вьет. си́cси, бенг. (কাকিল [кокил], маратхи कोकिळा [кокила], гуджарати કોયલ [коал], тамильск. குயில் [коел], телугу కోకిల [кокле], кит. 咕咕 [гугу], тагальск. kuku, япон. カッコウ [каккоу] и др. Это звукоподражание используется и в научном латинском термине Cuculus. Вероятно, нет в мире другого ономатопоэтического слова, столь совпадающего в обозначении какого-либо предмета или явления.

Менее яркую ономатопоэтическую традицию именования кукушки, также основанную на звукоподражательном эффекте, отражают рус. зегзииа, укр. зозуля, белор. зязюля, чеш. žežhule, словац. žežhulica, польск. gżegżótka, латыш. dzeguze, лит. gegute, др.-прус. geguse, которые восходят к звукоподражательному корню *-geg- с не до конца понятными фонетическими преобразованиями. М. Фасмер обнаруживает здесь дистантные ассимиляции (Фасмер, т. 2, с. 91-92). Л.А. Булаховский пишет: «Серьезные трудности представляет объяснение внешней формы слова» [Булаховский, 1948, c. 108]. Отметим, что в обоих случаях в инициальной позиции этимологического корня находятся заднеязычные звуки, которые, по наблюдениям Е.В. Тишиной, обладают звукоизобразительным признаком, «реализуя фоноизображение гортанного, резкого, громкого звука» [Тишина, 2010, с. 6], что, вероятно, отразило восприятие крика кукушки славянами и балтами.
Разнообразное фонетическое и деривационное оформление звукоподражательных номинаций кукушки обнаруживается в русских народных говорах. С точки зрения вокалического оформления корня лексемы распределяются на две группы: кок- и кук-. С корнем кок- зафиксировано 7 слов: коковка, кокука, кокуля, кокуша, кокушка, кокушечка и кокушица. Корень кук- отмечен в 20 дериватах, хотя, возможно, некоторые из них с единичным пунктом распространения могут отражать нечеткость или ошибочность записи: кукикша, кукованя, куковка, куковятина, кукувница, кукукалка, кукулка, кукуля, кукунья, кукуня, кукуха, кукуша, кукушечка, кукушиха, кукушица, кукушка, кукша, куникша, кушка, кушкушка. Во втором слоге [о] обнаруживается всего в четырех случаях: коков$\kappa a$, кокованя, куковка и коковятина. В остальных номинациях представлен звук [y], за исключением не очень ясной кукикши (куникuи) и таких же загадочных кукши и кушки в единичных употреблениях. В большинстве обследованных районов европейской части России используется лексема кукушка $(74$ \% от 848 случаев употреблений названия с корнем кук- / кок-), 9 \% приходится на кукушу, $8 \%$ - на кокушку, по $2 \%$ составили кукушииа и кукуля, $1 \%$ - коковка, по 0,5\% куковка, кукуня, кукуха, 3,5\% распределились среди остальных 18 наименований. Носители русской лингвокультуры понимают происхождение этого наименования птицы: Кукушкой называют, потому что она кричит ку-ку (270) ${ }^{2}$.

Вторая группа наименований, восходящих к этимону *gegŭza, существенно уступает по количеству районов фиксации, их всего 71. При этом слова можно распределить на две подгруппы: с начальным зоз-/зез-/зуз-/заз-/зяз( $80 \%$ от общего количества) и с зег-/заг-/жег(19\%), наименование загозуля является контаминированной формой (1 \%). Значительная часть единиц первой подгруппы прямо или косвенно отражает украинское или белорусское влияние, они записаны в восточнославянском этническом пограничье или в местах обитания носителей говоров с украинской языковой основой (Кубань, Старополье): зазуля, зозуля, зозулька, зозюля, зозуря, зезюля, зязуля, зузуля, зузюля. Г.М. Левина отмечает, что в Псков- 
ской и Смоленской областях на границе с Беларусью были зафиксированы названия кукушки зазуля, зазюля, зезуля, зезюля, зозуля, зузуля, зюзюля, зезюлик [Левина, 1975, с. 72]. Во второй подгруппе 4 названия образуют словообразовательное гнездо (загоза, загоска, загостка, загошка), особняком стоят жегож$\kappa a$ и зегзища. Она обнаружила еще несколько наименований этого типа: загозочка (Смоленская область), загозка (река Свирь), загонька (Псковская и Новгородская области), загож$\kappa a$, загоженька (Олонец), загошица, зогза (Вологодская область) [Левина, 1975, с. 72]. У поэта Н.А. Клюева, уроженца Олонецкой губернии, есть строки: Белая берёзонька / Клонится к дождю.. / Не кукуй, загозынька, / Про судьбу мою... (Клюев). Жегожка, отмеченная в Кирсановском районе Тамбовской области, весьма напоминает западнославянские диалектные наименования кукушки. В СРНГ отмечается, что это слово известно также в Олонецкой губернии.

О зегзище существуют обширная литература, прежде всего связанная с толкованием двух мест в «Слове о полку Игореве». Как свидетельствуют данные картотеки ЛАРНГ, этот орнитоним встречается на севере - в Сунском районе Кировской области и Суксунском районе Пермской области. Первоначально, с убедительными примерами из исторических документов («Палея» XIV в., «Мерило Праведное» XIV в., «Задонщина» конца XIV - начала XV в., «Вопросы святого Сильвестра и ответы преподобного Антония» XVI в.), это слово было истолковано как 'кукушка'. Удаленные от нас на шесть-семь веков тексты содержат такое же гневное осуждение поведения кукушки, как это обнаруживаются и у современных диалектоносителей: Зогзуля 8 чюжа гн тзда яиия своя мечеть (Мерило Праведное); Есть убо ина птииа, нарицаема зегула, есть убо птица та злонрава сущи, егда убо народить яица, то ин $\mathbf{k} x ъ$ птиць [въ гн $\mathbf{k} з д а] ~ я и ц а ~ с в о я ~ и з н о с и т ь ~ и з ъ ~ г н ~ \mathbf{~ з д а , ~}$ сама же своему гн взду не хранитель есть, но инымь птицамь отроды своя прем қтаеть (Палея Толковая).

Н.В. Шарлемань, опираясь на контекст, предположил, что «автор “Слова...” сравнил Ярославну с той птицей, которая издавна на Украине была эмблемой печали, то есть с чайкой» [Шарлемань, 1948, с. 115]. Эту интерпретацию поддержал Н.А. Мещерский: «С точки зрения поэтического образа это значение слова зегзица значительно лучше мотивируется, чем общепринятое ранее (кукушка)» [Мещерский, 1995, с. 171].

В поэтических и прозаических переложениях «Слова о полку Игореве» на современный язык отражены разные интерпретации этого слова. В.А. Жуковский знал о том, что у слова зегзица есть значение 'кукушка', но почему-то при редактировании заменил его на чечётку: Голос Ярославнин сльшшится, на заре одинокой чечёткою кличет: «Полечу, говорит, - чечёткою (зачеркнуто кукушкою. - Е. Б., В. С.) по Дунаю (Слово Ж., с. 36). Чечетка - это 'небольшая птица семейства вьюрковых (обитает в тундре и в лесной части Евразии и Америки' (БТС, с. 1479).

Д.С. Лихачев придерживается версии о кукушке: На Дунае Ярославнин голос сльшится, кукушкою безвестною рано кукует. «Полечу, - говорит, - кукушкою по Дунаю» (Лихачев, с. 211). Вслед за ним и Н.А. Заболоцкий говорит о кукушке: Плачет, из Путивля долетая, / Голос Ярославны молодой: / Обернусь я, бедная, кукушкой (Заболоцкий, c. 23). А.Ю. Чернов предложил новый взгляд на это слово, опираясь на обнаруженное Г.М. Левиной в воронежских говорах слово зегзииа 'иволга', и дал такой перевод отрывка из плача Ярославны: «По Дунаю поутру иволгою полечу» (Слово Ч., с. 47). Между тем задолго до появления работ Г.М. Левиной, в 1886 г., это слово с тем же значением было отмечено в курских говорах, оно включено в СРНГ (вып. 11, с. 244). Материалы ЛАРНГ показывают, что у этого орнитонима в русских народных говорах имеется также значение 'кукушка'. В последнем по времени переводе А.А. Бурыкина, ученика Н.А. Мещерского, зегзииа определяется как 'чайка': На Дунае голос Ярославны слышится, чайкой-зегзицей неведомой рано утром голосит [Бурыкин, 2017, с. 306]. В этой же книге дается обзор различных интерпретаций этого орнитонима [Бурыкин, 2017, с. 367].

В этой работе и во многих других дается ссылка на «Моление Даниила Заточника», однако И.И. Срезневский неслучайно не включил в свой словарь пример со словом зогзи- 
цุa, так как в изначальном тексте произведения эта лексема отсутствует: Да не възненавидим буду миру со многою бес ъдою, Яко же бо птиця, частяще п tсни своя, скоро възненавидима бываеть (Заруб., с. 73) (см. также: [Соколова, 1993, с. 255]). Она попадает в одну из поздних версий - в так называемую вторую редакцию, существенно отличающуюся от первоначального текста: Уподоблюся зогзицы, иже едину поеть песнь, того ради ненавидима бываеть (Заруб., с. 107). Л.В. Соколова считает, что автор «Моления», основываясь на тексте «Слова», в то же время спорит с ним, пародирует его, высмеивает Даниила и его послание: «Таким образом, “Моление” является вторичным по отношению к “Слову” памятником. Это ответ на “Слово”, анти-“Слово”, пародия на него» [Соколова, 1993, с. 230]. О «скоморошьем балагурстве» автора «Слова» и «Моления» говорил и Д.С. Лихачев [Лихачев, 1987, с. 154244]. Возможно, и простонародная зогзииа попала в текст в пародийных, балагурных целях. При этом контекст XV в. не может быть однозначно истолкован в пользу значения 'кукушка': надоесть своим однообразным пением может любая птица.

У кукушонка номинаций меньше, почти все они образованы от соответствующего названия кукушки с помощью суффикса -онок-/ -ёнок- с вариациями форм множественного числа: по древней модели -ama(bl)/-яma(bl) и с выравниванием парадигмы -онки/-ёнки. Дериваты с заг-/зоз- единичны: загосята, зозулёнок / зозулята, зузуленя (последнее явно украинского происхождения). Особняком стоят образования зобзун и зобун, всего по два употребления, причем на удалении друг от друга: первое в Чердынском районе Пермской области и Кирсановском районе Тамбовской области, второе - в Архангельском районе Башкирии и Дубровском районе Брянской области. Слово зобзун в переносном значении встречается также в беломорской старине «Михайло Игнатьевич (Данилович)», записанной 22 августа 1898 г. в селе Нижняя Зимняя Золотица на берегу Белого моря: Отговорит-от князь Владимер таковы речи: / «Tbl молодой зобзун, ты рано всё попа́рхивашь; / Потеряшь ты свою буйну голову nо-напрасному» (Беломор., с. 334). Эти сло- ва, вероятно, образованы от глагола зобти 'есть' (СРНГ, вып. 11, с. 325).

Остальные номинации образованы от корня кок-/кук-: от первого варианта всего 22 фиксации (коковёнок, кокунёнок / кокунёнки, кокушонок / кокушата / кокушатки), зато регулярная форма кукушонок / кукушата(bl) / кукушонки зафиксирована 876 раз (одна форма множественного числа - кукушьята). Другие формы малочисленны: по 9 районов - куковёнок / куковята, куколёнок, кукошонок / кукошонки, 7 районов - кукунёнок / кукуняma(bl), 6 районов - кукурёнок / кукурята / кукурёнки; кукушенёнок / кукушенята / кукушенятки. Отмечены также единичные употребления куклёнок / кукляты / кукленята; куколёнок, куконёнок / куконята; кукошонок / кукошата; кукуёнок / кукуята, кукужата; кукулёнок / кукулята; кукунчик, кукучонок / кукучата; кукушатко / кукушата; кукушеня / кукушата / кукушенята; кухарёнок; кушкушонок / кушкушата; кушонок / кушата; кукушоночек; кукушочек. Формы множественного числа некоторых наименований свидетельствуют о том, что здесь использовались другие формы единственного числа, но были вытеснены в лингвосознании диалектоносителей литературной формой: кукушонок / куканята, кукушонок / куковяты, кукушонок / кукушенята, кукушонок, кукушнята. Формы множественного числа оказываются более устойчивыми в диалектном лингвосознании.

Кукушка неизменно привлекает внимание диалектоносителей. Они подмечают, где живет птица, как она выглядит, чем питается, как относится к своим детям и пр. Скрытность кукушки, ее бросающиеся в глаза особенности жизни, звонкий голос послужили основой для рождения в народном лингвосознании целой системы поверий, предрассудков, воплощенных в фольклорных текстах умозаключений о реальном и мнимом в поведении этой птицы. Однако многое для жителей сел в жизни кукушки непонятно: Кукуша - загадочная птица. Кукушку не видно средь кустов (828). Связано это с тем, что кукушка - птица скрытная, но громкая: Кукушки обычно сидят в листве, их не видно, но сльшно (336); Кукушку увидеть трудно, она прячется в листве (847). Даже 
опытный орнитолог профессор Ленинградского университета А.С. Мальчевский отмечает: «До сих пор кукушка остается самой загадочной нашей птицей» [Мальчевский, 1987, c. 10].

Диалектоносители отмечают, что кукушка - лесная птица: Кукушка - это птичка лесная (332); Кукушка - такая лесная птица (436); Кукушка - это лесная пташка (467). Орнитолог отмечает: лес - родная стихия кукушки [Мальчевский, 1987, с. 32].

Главная черта в поведении кукушки заключается в том, что эта птица не вьет гнезда: Кокушка - нахальная птица. Не вьёт гнезда, не свивает гнёздышка (59); Птица, которая не вьёт своего гнезда, - кукушка (336); У кокушки нет гнезда (381); Серенькая кукушка, та гнезда не вьёт (801). Поскольку у кукушки нет гнезда, она подкладывает свои яйца в чужие гнезда. Ученые называют такой характер поведения птиц гнездовым паразитизмом [Makatsch, 1949; Molnar, 1944]. Жители сел в разных местах России подмечают эти действия птицы и дают им отрицательную оценку: Кукушки откладывают яйца в чужие гнёзда, те птички кормят их, а свои птенчики погибают, потому что кукушки прожсорливы (7); Кукуля откладывает яйца в чужие гнёзда (48); Кокушка - нахальная птица. Не вьёт гнезда, не свивает гнёздыика (59); Кукушка свои яйца в чужие гнёзда подкидывает (94); А они кукушки вредные птицы, кукушат своих бросают (120); Нахалка эта птииа (135); Кукушка - нехорошая птииа. Яна свои яйца в чужие гнёзда подкладывая (168); Кукушка снесёт своё яичко да не парит (206); Кукушиха - птица хитра, ленится птенчат высижсвать, вот и разносит яйца по всем другим гнёздам (207); Плохая мать кукушка (216); $A x$, эта кукушка, ведь самая грешная мать (337); Она свои яйца в чужие гнёзды кладёт, а потом летит по лесу и детей своих ищет (383); Кукушка птица-то красива, но плоха (438); Кукушка - плохая птииа, детей своих подбрасывает (433); Кукушка - мать непутёва (485); Гадкая птииа эта коковка (597); Кукушка - птииа проклятая, она детей бросает (898); Так она ещё и хорошие яйиа колет (329). Иногда проявляется сочувствие к птице: Какая из кукушки мать, кукушат своих другим птииам подбрасываеть. А что ж, гнезда она не вьеть, где ей кукушат растить (430); Кукушка всё горемыкается. Яич-то она не выводит, кукушка-то (529); Кукушка закуковала: то ли счастья ищет, то ли кукушонка своего. Кукушка потом кукушонка своего ищет. Летает кукушка, тоскует. Кукушка одна всё время кукует, ищет кого-то. Говорят: кукушка кукует, своего мужа ищет (845a). Для обозначения подбрасывания кукушкой яиц в чужие гнезда используются различные глаголы: кладёт, откладывает, подкладывает, подбрасываem, подкидыввает, отложит яйца. В записях народной речи встречается уточнение: Кукушка сама яйца не высиживат. Она их подбрасыват в другие гнёзда махоньких птичек (451); Кукурята в чужом гнезде pacmym (387).

Появилось народное объяснение причин такого поведения кукушки: Кукушка в Троииу-то яйца снесла и куковала весь день. Бок и наказал её, што ни дома, ни детей у неё нет (51).

В орнитологии птицы, на которых паразитируют кукушки, называются воспитателями. К ним относятся горихвостка-лысушка, белая трясогузка, зарянка (малиновка) и дроздовидная камышевка, выводящие половину кукушат [Мальчевский, 1987, с. 147]. Народ подтверждает эти наблюдения: Кукушика подкладывает яйиа дрозду малиновке, выводится кукушонок, кукушата. Малиновка кормит своих и кукушат (681); В гнезде малиновки ай видал кукушонка (438), однако и расширяет список воспитателей: Синица, филин, коршун кормят кукушонка, пока тот не научится летать, а сама кукушка не парит птенцов (51); Ворона высиживает воронят и кукушат (59); В гнёздышке дятлика вылупился кукушонок (187); Матькукушка своих птениов другим птицам отдаёт. Вот и вырастает в семье дятла кукушонок (381); Зобзуна кормит грачиха (598); Кукушка птенцов не выводит, выводят другие. Скобеи выводит (984); Воробьи выкормили в своем гнезде кукушонка (384); У галки примач (764); Кукушонок в гнезде у ласточек был (833). Кукушка может подбросить яйца и домашней птице: Бабы баяли, 
што курица вывела кукушат (18); У гусей кукушонок вывелся (170). Ученые отмечают, что кукушки паразитируют на определенных видах птиц. Например, кукушка часто подбрасывает яйца в гнезда зарянки [Мальчевский, 1987, с. 29, 65].

Повсеместно распространено утверждение, что эта птица предсказывает, сколько лет человеку осталось прожить. Считается необходимым обратиться к кукушке с просьбой посчитать года, эти фразы повторяются почти дословно в разных частях России: Кукушка, кукушка, сколько мне жить осталось (45); Кукуша, кукуша, сколько мне лет жить осталось (84); Кукушиияа предвещает, сколько нам жить осталось (145); В лесу и спросишь, бывало, кукушку: Сколько лет мне жить осталось (189); Если кукушка закукуе, то начнём щитать, а сами думаем: «Кукуня, ну, ни останавливайся». Толька бы не остановилась (274); Eсть у нас поверье, что сколько лет кукушка прокукует, столько лет ты и жить будешь. Кукушка накуковала сто лет (287); Кокушка, кокушка, сколько мне жить осталось? (302); Птииа кукушка года отщитывает, кому сколько. Кукушка кричит: «Ку-ку», а люди считают (381); Кукуля, сколько лет мне жить? (438); Кукушка, скажи, сколько я лет проживу (950); Кукушки птиць невзрачные, серые, но люди в лесу всегда считают, сколько раз она прокукует, верят в приме$m y$ (406). Носители русской лингвокультуры понимают, что это игра, поэтому добавляют: Не верю я этим кушкушкам (389); Кукушка-тот ещё пророк, да не верьте ей (337); Кукушка тебе скажет, сколько жить осталось, верить только не стоит (592). Ученые-орнитологи насчитали максимальное количество фонаций кукушки - 360 [Мальчевский, 1987, с. 67].

В народе не отличают кукушку-самку от самца: Кукушка и есть кукушка, хоть самеи, хоть самка (34); Самку тоже кокушкой называли, не различали, где самеи, где самка (156); И жена кукушки тоже кукушка (288); Самочка тоже кукушкой будет (381); Мы самку всё одно кукухой зовем, их ведь не отличишь (401); И самка, и самеи всё равно кукушка (436); Кукушка она и есть кукушка, што самка, ито самец (437);
Её так же и зовуть, как ево, - кукушка (950). Однако некоторые жители сел дают отдельные названия самцу и самке и знают, что кукует только самец: Кокуй - самец кукушки. Кокуй кукует (116); Кукует кукуш (18); Говорят, что самка кукушки не кукует (61); Самоику называм кукушиной (61); Ведь кукушка сама ни кукует, это папа поёт (395); А ишио её кукушицей зовут у нас, ет когда ана самачка, мать детей своих (437); Самку кукушки звали у нас кукушиха (432); Жена у кукушки кукушиха (527); Кукун самеи кукушки (845a).

Орнитологи подтверждают, что во время токования кукует всегда самец, он подает брачный сигнал, у самки иной голос, не такой звонкий. Голос же самца слышен далеко, в тихую погоду на два километра [Мальчевский 1987, c. 15], что и стало, видимо, одной из причин приметы о подсчете будущих лет жизни: у других птиц нет столь четких, громких и повторяющихся фонаций.

Народ примечает, когда начинается и как долго длится брачный сезон у кукушек: Обычно у нас второго мая прилетает кукушка, да сегодня я не сльшиал (332); За первой грозой зозуля кукует (730); Кукушка начинает куковать, когда на деревьях первые листья. Кукует да двенадиатого июля, до Пятра (377); Говорят, кокушка кокует только до Петрова дня (295); Кукушки вот сейчас до Петрова дня, а больше петь не будут (386); Кукушка до Петрова дня поёт (395); Кукуша будет куковать до Петрова дня, а там улетит (845a); Теперь уж кукушка откуковала. Пятров день прошёл. Больше не будет куковать (549).

Орнитологи указывают, что активное кукование самцов начинается после прилета самок, которые задерживаются в местах зимовки. В разных регионах России это происходит в разные сроки: на юге можно услышать кукушку даже в конце марта, но в средней полосе обычно брачные игры кукушек начинаются 2-5 мая [Мальчевский, 1987, с. 28]. Заканчивается кукование к середине июля, ко Дню святых апостолов Петра и Павла, который приходится на 12 июля. К этому времени наливается колос у зерновых, поэтому в народе говорят: Когда ячмень на зерно выйдет, уж тогда кукушка попускается, не кукует 
E.В. Брысина, В.И. Супрун. Названия кукушки и кукушонка в русском народном лингвосознании

больше (42); Перестала куковать - подавилась ржаным колосом (61). Последняя поговорка широко распространена в русском диалектном континууме, она отмечена в СРНГ: Кукушка колосом (ячменем) подавилась (давится). О времени созревания ржи, ячменя (когда кукушка перестает куковать) (СРНГ, вып. 16, с. 48) (см. также: [Мальчевский, 1987, с. 21]).

С кукушкой связан ряд народных примет: Кукушка прокуковала - можно купаться (562); Ой, кокушка прилетела, тепло будет (314); Прилетела кукушка на гольй лес - к плохому году (61); Ой, кукушка кукует на гольий лес - урожай плохой будет (469); Кукушка - птица нехорошая. В окно стучит - к худому (52); А кокушка в деревню прилетит - беда будет (351); Если кукушка на улииу какую прилетела, к пожару это (206); Кукушка кукует - это к пожару (281); Зегзииа в лесу кричит, примечай, в какое ухо - худо, как в левое (214); Весной усльишишь кукушку первую - к засухе (321); Мороз будэ, коль зозуля на сухом дэрэви кукуе (1026). О народных приметах упоминает орнитолог А.С. Мальчевский: Закуковала кукушка - пора лён сеять; Ранняя кукуш$\kappa a$, до листа - к неурожаю, голоду [Мальчевский, 1987, с. 27].

Внешне кукушка похожа на ястребаперепелятника. Это стало основой народного предания о том, что, перестав куковать, кукушка превращается в ястреба и таскает цыплят и кур: Кукушка - она подбрасывает яйиа, тягает и иыплят (324); Кукушка в деревне таскат маленьких птииьках (529); Кукушка да Пятра кукуя, а патом курей крадёть. После Пятра она зовётся рялок (267). Нам не удалось обнаружить слово релок / рялок в доступных диалектных словарях, но, судя по контексту, оно обозначает какую-то хищную птицу, а с учетом ее сходства с перепелятником можно предположить, что речь идет о нем. В другом контексте отсутствие кукования у кукушки летом объясняется ее превращением в сову: Кукушка кукуеть, а с пол-лета делается на сову (269).

Народ то ли по наблюдениям, то ли по книгам знает о пищевых предпочтениях кукушки: Кукушки клюют вредных насекомых (539); Кукушка питается различными насе- комыми, поедает много волосатых гусениц, которых обычно не едят другие птииы (134); Кукушки насекомых едят (811).

Диалектоносители обращают внимание на внешний вид и поведение детеныша кукушки. Во многих контекстах выражается сочувствие его сиротской доле, но отмечается и агрессивный характер птенца: Кукушата они нищасные, без матери живут. Чужая птиияа, может, накормит, а может, и выкинет (383); Кукушат чужая мать выводит, кормит их как родных, воспитывает, обучает летать (467); Кукушонок тот в лесу жил одиноко (342); Кокушонок-то из гнезда всех птенцов выкидывает (38); Кукушонок крупный по сравнению с другими птениами. Кукушата ну очень прожсорливы (48); Кукушонок, если в гнездо какой птичке попадёт, всех птенцов вытолкнет, один останется (62); Кукушаты - они в чужых гнёздах выводются (70); Кукушата у матери не растут, их другие птииы растят, а кто и заклевывает (466); Кукушата вылупляются гадкие, с большой головой, на лапках не стоят (83); Кукушата - самые прожорливые из птениов (84); Кукушата вредные, своих меньших братьев выталкивают (104); Подросший кукушонок выкидыват из гнезда других птенчов, а их родители продолжают его кормить (134); Кукушонок некрасивый птенеи (189); Кукушата - подкидыши (241); Кукушонок всех птениов выкинет, а птички его кормят (270); Кукушоонок всех из гнезда вышвырнул (296); Кукушонок такой же злой, как мать (344); А кукията других птенцов-то не любят, из гнёзд выкидывают (478); Кукавёнак всех других птиниов повыкидавал (745); Так он ешё и хозяйские яйиа сосёт (801); Когда выводится кукушонок, всех из гнезда выбрасываеть (845а); Кукушонок выталкивал птенцов из гнезда (954); Кукушатко выкыдывае из гнизда иншых птынииив (1027).

Кукушка за свои необычные качества становится популярным героем фольклорных текстов. Л.Ю. Гусев включает ее наименование в число ядерных единиц лексико-семантической группы в текстах былин, причитаний, лирических и исторических песен [Гусев, 1996, с. 9]. Она часто встречается в песнях, которые напевают или пересказывают диа- 
лектоносители: Не кокушечка кукует, не соловушек поёт (285). Текст этой народной песни имеет варианты: Не кукушечка кукует / Не соловушка поёт. / Рано маменька (Родна маменка) тоскует: / Сын в солдатики идёт. / Не кукушечка кукует / Не соловушка поёт. / Мать по дочери горюет - / Лодырь свататься идёт. Существует частушка: Не кукуй, кукушечка, в лесе, вылетай в поле (100). Полностью она звучит так: Не кукуй, кукушка, в лесе, / Вылетай в полюшко. / Не тоскуй, моё сердечко, / Не вдавайся в горюшко. В годы коллективизации на ее основе сочинили политическую частушку: Не кукуй, кукушка, в лесе, / Вылетай на полюшко, / Бедняку совет - защита, / А буржу$я м$ - горюшко.

Наиболее часто сельские жители вспоминают песню «Соловей кукушечку уговаривал»: Соловей кокушечку уговаривал (402); Есть песня: Соловей кукушку уговаривал (527); Соловей кукушку уговаривал: Полетим, кукушка, в тёмный лесок (529); Выведи, кукушка, двух детёнышей: тебе кокорёнка, а мне соловья (212); Полетим, кукуи$к а$ в в тёмненькой лесок. Будет два птениа: тебе кокушонка (393); Выведем, кукушка, два детёныша: тебе куковёнка, а мне соловья (475). Эта протяжная народная песня впервые была зафиксирована еще знаменитым собирателем народных песен, писателем и фольклористом П.В. Киреевским, пять ее вариантов, записанных им в Орловской и Московской губерниях, вошли в издание Общества любителей российской словесности (Киреев., c. 13-16). Песня относится к былевым, историческим песням периода правления Ивана Грозного; она была связана со взятием Казани. Позже появились новые текстовые и мелодические варианты, она была распета казаками, духоборами, различными современными российскими ансамблями. Так, профессор Воронежской академии искусств Г.Я Сысоева записала песню в селе Нижняя Покровка Белгородской области и включила ее в репертуар своего ансамбля «Воля». Со временем песня из исторической превратилась в лирическую, тема взятия Казани, как неактуальная, перестала в ней звучать.

Жители сел помнят некоторые выученные в школе произведения художественной литера- туры, в которых упоминается кукушка, например басню И.А. Крылова: Кукушка хвалит петуха (591), стихотворение С.Я. Маршака: В лесу над росистой полянкой кукушка встречает рассвет (591). В их памяти хранятся народные сказки и простое стихотворение неизвестного автора: Кукушонок закричал, яйца все пораскидал (стих) (325); Правнучку я люблю сказку про кукушку с кукушатами рассказывать (344); И сказка есть про то, как кукушонок у других птии рос (433).

Многие диалектоносители вспоминают скороговорку, которую тоже, вероятно, слышали в школе: Кукушка кукушонку купила капишон (121); Про кукушонка скороговорка одна есть (137); Кукушка кукушонку сшила капюшон, как в капюшоне он смешон (216); Купила кукушонку кукушка капюшон, кукушонок в капюшоне очень смешон (260); Ишо у нас такая скороговорка про кукушат была, да забыла я её чёй-то (437).

Широко представлены в народной речи слова кукушка и кукушонок в переносных значениях, пока не вошедших в словари русского языка.

Кукушка. 1. Мать, бросившая своих детей или не заботящаяся о них: Да вон у Гальки мать всё кокушкой звали (44); Женщину, какая бросит детей, так называют (260); Иная и девка как кукушка (979); Вот она как кукушка - дети без присмотра (466); Мы плохую мать кукушкой называем (380). 2. Забывчивый человек (чаще о женщине): И куда это я обрядила. Вот кукушка. Беспамятная потому что (70).

Кукушонок. Ребенок, брошенный родителями или матерью: Нет у него родного отиа и родной матери - кукушонок (61); Кукушатами детей покинутых зовут (342); Кукушаты - брошенные дети (774); Кукушатами ещё сирот называют. А ведь и у людей кукушата бывают (592).

Слово кукушонок используется в сравнительных оборотах и как ласковое именование ребенка: Смотрю: детки сидять, словно кукушата какие (959); О, какой большеротый, што кукушонок. Прожорливые, как кукушата (277); Пищит, как кукушонок (265); Маленький кукушоночек (о ребенке в капюшоне) (774); Еле нашла своего кукушон$\kappa a(845 a)$. 
Видимо, уже вышел из употребления обряд крещения и похорон кукушки, описанный фольклористами [Бернштам, 1981; Виноградова, 1999; Гура, 2004]. Он был распространен на территории Калужской, Орловской, Тульской, Курской, Брянской, Белгородской областей, но в картотеке ЛАРНГ не зафиксирован.

В различных лингвистических и этнографических источниках используются устойчивые сочетания, содержащие слово кукушка. У В.И. Даля обнаруживается более 40 пословиц и поговорок. Их анализ может стать предметом отдельной статьи.

\section{Выводы}

Современная отечественная этнолингвистика изучает отношения между языком и культурой, языком и народом, особенности восприятия мира разными субэтническими (диалектными) группами. Объекты окружающей экосистемы получают в народной речи дифференцированные номинации в зависимости от физико-географических и социальных условий мест проживания носителей говоров. Мир флоры и фауны отражается в лингвосознании представителей различных русских диалектных сообществ многообразием лексикосемантических и фразеологических единиц, что подтверждается изоглоссами на картах ЛАРНГ. Существуют также универсальные лексико-фразеологические средства языка, относящиеся к тому или иному объекту природы. Одной из таких номинаций является орнитоним кукушка (с фонетическими и деривационными вариантами), отмеченный на территории практически всей европейской части России.

Исследование показало, что наименования кукушки и ее птенца занимают значительное место в лингвосознании русского народа. Эти единицы имеют ономатопоэтическое происхождение, они испытали в русском диалектном континууме фонетические, деривационные и семантические преобразования. В семантике данных орнитонимов отражается «бинарная корреляция» (о термине см.: [Денисова, Кутьева, 2011, c. 108]), связывающая сферу живой природы, к которой они принадлежат по денотативным признакам, и сферу человеческого характера - об- ласть, куда приводит их развитие коннотативно-контекстуальной семантики, обусловленное спецификой лингвокреативного мышления языковой личности. В диалектной речи происходят процессы семантического развития единиц. Орнитонимы кукушка и кукушонок употребляются с метафорическими переносами, относящимися к номинациям человека.

\section{ПРИМЕЧАНИЯ}

${ }^{1}$ Статья выполнена при поддержке РФФИ, грант № 19-412-340004 «Духовная культура казачества как поликультурная толерантная среда: язык и образы».

The research was funded by Russian Foundation for Basic Research, grant no. 19-412-340004 "Spiritual culture of the Don Cossacks as a multicultural tolerant environment: language and images".

2 Здесь и далее указаны отмеченные в ЛАРНГ номера населенных пунктов, в которых записан диалектный текст (с. 12-19).

\section{СПИСОК ЛИТЕРАТУРЫ}

Бернштам Т. А., 1981. Обряд «крещение и похороны кукушки» // Материальная культура и мифология. Т. 37 : сб. ст. / отв. ред. Б. Н. Путилов. Л. : Наука. С. 179-209.

Булаховский Л. А., 1948. Общеславянские названия птиц // Известия АН СССР. ОЛЯ. Т. 7. Вып. 2 / отв. ред. И. И. Мещанинов. М. ; Л. : Изд-во АН СССР. С. 97-124.

Бурыкин А. А., 2017. Слово о полку Игореве: текст, язык, автор. СПб. : Петербург. востоковедение. $416 \mathrm{c}$.

Виноградова Л. И., 1999. Крестить кукушку // Славянские древности: этнолингвистический словарь. В 5 т. Т. 2 / под общ. ред. Н. И. Толстого. М. : Междунар. отношения. С. 672-674.

Гура А. В., 2004. Кукушка // Славянские древности: этнолингвистический словарь. В 5 т. Т. 3 / под общ. ред. Н. И. Толстого М. : Междунар. отношения. С. 36-40.

Гусев Л. Ю., 1996. Орнитонимы в фольклорном тексте : автореф. дис. ... канд. филол. наук. Курск. $20 \mathrm{c}$.

Денисова А. П., Кутьева М. В., 2011. Орнитоним «кукушка» в языковой картине носителей русского и испанского языка // Вестник Российского университета дружбы народов. Серия: Русский и иностранные языки и методика их преподавания. № 3. С. 98-108.

Левина Г. М., 1975. Кукушка, кокушка, загоска // Русская речь. № 6. С. 71-72. 
Лихачев Д. С., 1987. Избранные работы. В 3 т. Т. 2. Великое наследие; Смех в Древней Руси ; Заметки о русском. Л. : Худож. лит. 496 с.

Мальчевский А. С., 1987. Кукушка и ее воспитатели. Л. : Изд-во Ленингр. гос. ун-та. 264 с. (Cерия «Жизнь наших птиц и зверей» ; вып. 9).

Мещерский Н. А., 1995. К вопросу о территориальном приурочении первоначального текста «Слова о полку Игореве» по данным лексики // Избранные статьи / отв. ред. и сост. Е. Н. Мещерская. СПб. : Яз. центр филол. фак. СПбГУ. C. $153-186$.

Соколова Л. В., 1993. К характеристике «Слова» Даниила Заточника : (Реконструкция и интерпретация первоначального текста) // Труды Отдела древнерусской литературы. Т. 46 / отв. ред. Д. С. Лихачев. СПб. : Дмитрий Буланин, 1993. С. 229-255.

Тишина Е. В., 2010. Русская ономатопея: диахронный и синхронный аспекты изучения : автореф. дис. ... канд. филол. наук. Волгоград. 21 с.

Шарлемань Н. В., 1948. Из реального комментария к «Слову о полку Игореве» // Труды Отдела древнерусской литературы. Т. 6 / отв. ред. В. П. Адрианова-Перетц, И. П. Ерёмин. М. ; Л. : Изд-во АН СССР. С. 111-124.

Makatsch W., 1949. Unser Kuckuck. Wittenberg (Lutherstadt) : A. Ziemsen Verlag. $42 \mathrm{~S}$.

Molnar B., 1944. The Cuckoo in the Hungarian Plaine // Aquila. Vol. 51. Budapest : A Magyar Ornithologiai Központ Kiadványa. P. 100-112.

\section{ИСТОЧНИКИ И СЛОВАРИ}

Беломор. - Беломорские старины и духовные стихи : Собрание А. В. Маркова. СПб. : Дмитрий Буланин, 2002. 1080 c.

БTC - Большой толковый словарь русского языка / гл. ред. С. А. Кузнецов. СПб. : Норинт, 1998. $1536 \mathrm{c}$.

Заболоцкий - Заболоцкий Н. А. Собрание сочинений. В 3 т. Т. 2. Переводы / примеч. Е. Заболоцкой, Л. Шубина. М. : Худож. лит., 1984. 463 с.

Заруб. - Слово Даниила Заточника по редакциям XII и XIII вв. и их переделкам / пригот. к печати Н. Н. Зарубин. Л. : Изд-во АН СССР, 1932. XVI, $166 \mathrm{c}$.

Киреев. - Песни, собранные П.В. Киреевским. Изданы Обществом любителей российской словесности. Ч. 2. Вып. 6. М. : Тип. Лазаревского ин-та вост. яз., 1864. 212 с.

Клюев-Клюев Н. А. Стихотворения и поэмы / сост., подгот. текста и примеч. Л. К. Швецовой ; вступ. ст. В. Г. Базанова. 2-е изд. Л. : Сов. писатель, 1982.560 c.
ЛАРНГ - Лексический атлас русских народных говоров. Т. 1. Растительный мир. М. ; СПб. : Нестор-История, 2017.736 с.

Лихачев - Лихачев Д. С. Слово о полку Игореве // Изборник : сб. произведений лит. Древней Руси. М. : Худож. лит., 1969. С. 196-213, 715-726. (Библиотека всемирной литературы).

Мерило Праведное - Мерило Праведное по рукописи XIV века / изд. под наблюдением и со вступ. ст. акад. М. Н. Тихомирова. М. : Изд-во AHCCCP, 1961. XIV, $698 \mathrm{c}$.

Палея Толковая - Палея Толковая по списку, сделанному в Коломне в 1406 г. : в 2 вып. / труд учеников Н.С. Тихонравова. М. : Тип. и словолитня О. Гербска, 1892-1896. Вып. 1. 1892. 208 с. ; Вып. 2. 1896. 209-416 с.

Слово Ж. - Слово о полку Игореве / пересказ В. Жуковского. М. : Белый город, 2003. 48 с.

Слово Ч. - Слово о полку Игореве / под ред. А. Чернова. СПб. : Летний сад, 2010. 512 с.

Срезневский И. И. Словарь древнерусского языка. Т. 1. Ч. 2. М. : Книга, 1989. Стб. 806-1419, 49 с.

СРНГ-Словарь русских народных говоров. М. ; Л. (СПб.) : Наука, 1965-2018. Вып. 1-50 / гл. ред. Ф. П. Филин (вып. 1-23) ; Ф. П. Сороколетов (вып. 24-42); Ф. П. Сороколетов, отв. ред. С. А. Мызников (вып. 43-46); С. А. Мызников (вып. 47-50).

Фасмер - Фасмер М. Этимологический словарь русского языка. В 4 т. / пер. с нем. и доп. О. Н. Трубачева ; под ред. Б. А. Ларина. Изд. 2-е, стер. М. : Прогресс, 1986-1987.4 т.

\section{REFERENCES}

Bernshtam T.A., 1981. Obryad «kreshcheniye i pokhorony kukushki» [Rite of Passage "Baptism and Funeral Cuckoo"]. Putilov B.N., ed. Materialnaya kultura $i$ mifologiya: sb. st. [Material Culture and Mythology. Collection of Articles]. Leningrad, Nauka Publ., vol. 37, pp. 179-209.

Bulakhovskiy L.A., 1948. Obshcheslavyanskie nazvaniya ptits [Common Slavic Names of Birds]. Meshchaninov I.I., ed. Izvestiya AN SSSR. OLYA. Moscow, Leningrad, Izd-vo AN SSSR, vol. 7, iss. 2, pp. 97-124.

Burykin A.A., 2017. Slovo o polku Igoreve: tekst, yazyk, avtor [A Word About Igors Regiment: Text, Language, Author]. Saint Petersburg, Peterburgskoe vostokovedenie Publ. 416 p.

Vinogradova L.I., 1999. Krestit kukushku [To Baptize the Cuckoo]. Tolstoy N.I., ed. Slavyanskie drevnosti: etnolingvisticheskiy slovar. V 5 t. T. 2 [Slavic Antiquities: Ethnolinguistic Dictionary. 
In 5 Vols. Vol. 2]. Moscow, Mezhdunarodnye otnosheniya Publ., pp. 672-674.

Gura A.V., 2004. Kukushka [Cuckoo]. Tolstoy N.I., ed. Slavyanskie drevnosti: etnolingvisticheskiy slovar. $V 5$ t. T. 3 [Slavic Antiquities: Ethnolinguistic Dictionary. In 5 Vols. Vol. 3]. Moscow, Mezhdunarodnye otnosheniya Publ., pp. 36-40.

Gusev L.Yu., 1996. Ornitonimy v folklornom tekste: avtoref. dis. ... kand. filol. nauk [Ornithonyms in the Folklore Text. Cand. philol. sci. abs. diss.]. Kursk. 20 p.

Denisova A.P., Kutyeva M.V., 2011. Ornitonim «kukushka» v yazykovoy kartine nositeley russkogo i ispanskogo yazykov [Ornithonym "Cuckoo" in the Linguistic World View of Russian and Spanish Native Speakers]. Vestnik Rossiyskogo universiteta druzhby narodov. Seriya: Russkiy i inostrannye yazyki i metodika ikh prepodavaniya [Bulletin of Peoples Friendship University of Russia. Series: Russian and Foreign Languages. Methods of Its Teaching], no. 3, pp. 98-108.

Levina G.M., 1975. Kukushka, kokushka, zagoska [Cuckoo, Kakushka, Zagoska]. Russkaya rech [Russian Speech], no. 6, pp. 71-72.

Likhachev D.S., 1987. Izbrannye raboty. V 3 t. T. 2. Velikoe nasledie; Smekh v Drevney Rusi: Monografii; Zametki o russkom [Selected Works. In 3 Vols. Vol. 2. The Great Legacy; Laughter in Ancient Russia. Monographs; Notes on Russian]. Leningrad, Khudozhestvennaya literatura Publ. $496 \mathrm{p}$.

Malchevskiy A.S., 1987. Kukushka i ee vospitateli [The Cuckoo and Her Tutors]. Leningrad, Izd-vo Leningradskogo gosudarstvennogo universiteta. 264 p. (Seriya «Zhizn nashikh ptits i zverey» [Series "Life of Our Birds and Animals"], iss. 9).

Meshcherskiy N.A., 1995. K voprosu o territorialnom priurochenii pervonachalnogo teksta «Slova o polku Igoreve» po dannym leksiki [To the Issue of the Territorial Connection of the Original Text of "A Word About Igors Regiment" According to the Lexicon]. Meshcherskaya N.A., ed. Izbrannyye statyi [Selected Articles]. Saint Petersburg, Yazykovoy tsentr filologicheskogo fakulteta SPbGU, pp. 153-186.

Sokolova L.V., 1993. K kharakteristike «Slova» Daniila Zatochnika (Rekonstruktsiya i interpretatsiya pervonachalnogo teksta) [On the Characterization of the "Word" of Daniel Zatochnik (Reconstruction and Interpretation of the Original Text)]. Likhachev D.S., ed. Trudy Otdela drevnerusskoy literatury. T. 46 [Works of the Department of Old Russian Literature.
Vol. 46]. Saint Petersburg, Dmitriy Bulanin Publ., pp. 229-255.

Tishina E.V., 2010. Russkaya onomatopeya: diakhronnyy $i$ sinkhronnyy aspekty izucheniya: avtoref. dis. ... kand. filol. nauk [Russian Onomatopoeia: Diachronic and Synchronous Aspects of Study. Cand. philol. sci. abs. diss.]. Volgograd. $21 \mathrm{p}$.

Sharleman N.V., 1948. Iz realnogo kommentariya k «Slovu o polku Igoreve»[From the Real Commentary to "A Word About Igors Regiment"]. Adrianova-Peretts V.P., Eremin I.P., eds. Trudy Otdela drevnerusskoy literatury. T. 6 [Proceedings of the Department of Ancient Russian Literature. Vol. 6]. Moscow, Leningrad, Izd-vo AN SSSR, pp. 111-124.

Makatsch W., 1949. Unser Kuckuck. Wittenberg. Lutherstadt, A. Ziemsen Verlag. $42 \mathrm{~S}$.

Molnar B., 1944. The Cuckoo in the Hungarian Plaine. Aquila. Vol. 51. Budapest, A Magyar Ornithologiai Központ Kiadványa, pp. 100-112.

\section{SOURCES AND DICTIONARIES}

Belomorskie stariny i dukhovnye stikhi: Sobranie A.V. Markova [White Sea Starinas (Old Songs) and Spiritual Poems: The Collection of A.V. Markov]. Saint Petersburg, DmitriyBulanin Publ., 2002. 1080 p.

Kuznetsov S.A., ed. Bolshoy tolkovyy slovar russkogo yazyka [Big Explanatory Dictionary of the Russian Language]. Saint Petersburg, Norint Publ., 1998. 1536 p.

Zabolotskiy N.A. Sobranie sochineniy. V 3 t. T. 2. Perevody [Collected Works. In 3 Vols. Vol. 2. Translations]. Moscow, Khudozhestvennaya literatura Publ., 1984. 463 p.

Zarubin N.N., ed. Slovo Daniila Zatochnika po redaktsiyam XII $i$ XIII vv. i ikh peredelkam [Word of Daniel Zatochnik on the Editions of the $12^{\text {th }}$ and $13^{\text {th }}$ Centuries. and Their Alterations]. Leningrad, Izd-vo AN SSSR,1932. XVI,166 p.

Pesni, sobrannye P.V. Kireevskim. Izdany Obshchestvom lyubiteley rossiyskoy slovesnosti. Ch. 2. Vyp. 6 [Songs Collected by P. V. Kireevsky. Published by the Society of Lovers of Russian Literature. Part 2. Iss. 6]. Moscow, Tipografiya Lazarevskogo instituta vostochnykh yazykov, 1864. 212 p.

Klyuyev N.A. Stikhotvoreniya i poemy [Lyrics and Poems]. Leningrad, Sovetskiy pisatel Publ., 1982. $560 \mathrm{p}$.

Leksicheskiy atlas russkikh narodnykh govorov. T. 1 . Rastitelnyy mir [Lexical Atlas of Russian Folk Dialects. Vol. 1. The Plant World]. Moscow, Saint Petersburg Nestor-Istoriya Publ., 2017. 736 p. 


\section{РАЗВИТИЕ И ФУНКЦИОНИРОВАНИЕ РУССКОГО ЯЗЫКА}

Likhachev D.S. Slovo o polku Igoreve [Word About Igors Regiment]. Izbornik: sb. proizvedeniy lit. Drevney Rusi [Izbornik. Collection of Works of Literature of Ancient Russia]. Moscow, Khudozhestvennaya literatura Publ., 1969, pp. 196-213, 715-726. (Biblioteka vsemirnoy literatury [Library of World Literature]).

Tihomirov M.N., ed. Merilo Pravednoe po rukopisi $X I V$ veka [The Righteous Measure According to the Manuscript of the $14^{\text {th }}$ Century]. Moscow, Izd-voAN SSSR, 1961. XIV, $698 \mathrm{p}$.

Paleya Tolkovaya po spisku, sdelannomu $v$ Kolomne v 1406 g.: v 2 vyp. [Palea Tolkovaya According to the List Made in Kolomna in 1406. In 2 Iss.]. Moscow, Tipografiya i slovolitnya O. Gerbska, 1892-1896, iss. 1. 1892. 208 p.; iss. 2. 1896. 209-416 p.
Slovo o polku Igoreve [A Word About Igors Regiment]. Retelling by V. Zhukovsky. Moscow, Belyy gorod Publ., 2003. 48 p.

Chernov A.Yu., ed. Slovo o polku Igoreve [The Word About Igors Regiment]. Saint Petersburg, Letniy sad Publ., 2010. 512 p.

Sreznevskiy I.I. Slovar drevnerusskogo yazyka. T. 1. Ch. 2 [Dictionary of the Old Russian Language. Vol. 1. Part 2]. Moscow, Kniga Publ., 1989, cols. 806-1419, 49 p.

Slovar russkikh narodnykh govorov. Vyp. 1-50 [Dictionary of Russian Folk Dialects. Issues 150]. Moscow, Leningrad (Saint Petersburg), Nauka Publ., 1965-2018.

Fasmer M. Etimologicheskiy slovar russkogo yazyka. V 4 t. [Etymological Dictionary of the Russian Language. In 4 Vols.]. Moscow, Progress Publ., 1986-1987.

\section{Information About the Authors}

Evgenia V. Brysina, Doctor of Sciences (Philology), Professor, Head of the Institute of Russian Language and Literature, Volgograd State Socio-Pedagogical University, Prosp. im. V.I. Lenina, 27, 400066 Volgograd, Russia, filolog@vspu.ru, https://orcid.org/0000-0003-3755-5555

Vasiliy I. Suprun, Doctor of Sciences (Philology), Professor, Department of Russian Language and Methods of Its Teaching, Volgograd State Socio-Pedagogical University, Prosp. im. V.I. Lenina, 27, 400066 Volgograd, Russia, suprun@vspu.ru, https://orcid.org/0000-0003-2489-9199

\section{Информация об авторах}

Евгения Валентиновна Брысина, доктор филологических наук, профессор, директор Института русского языка и словесности, Волгоградский государственный социально-педагогический университет, просп. им. В.И. Ленина, 27, 400066 г. Волгоград, Россия, filolog@vspu.ru, https://orcid.org/0000-0003-3755-5555

Василий Иванович Супрун, доктор филологических наук, профессор кафедры русского языка и методики его преподавания, Волгоградский государственный социально-педагогический университет, просп. им. В.И. Ленина, 27, 400066 г. Волгоград, Россия, suprun@vspu.ru, https://orcid.org/0000-0003-2489-9199 